\title{
Collective Responsibility in the Press
}

Alain Rabatel and Roselyne Koren

Translator. Inist

\section{(2) OpenEdition}

\section{Journals}

Electronic version

URL: http://journals.openedition.org/questionsdecommunication/8870

DOI: 10.4000/questionsdecommunication.8870

ISSN: 2259-8901

Publisher

Presses universitaires de Lorraine

\section{Printed version}

Date of publication: 1 July 2008

ISBN: 978-2-86480-952-4

ISSN: 1633-5961

Electronic reference

Alain Rabatel and Roselyne Koren, "Collective Responsibility in the Press", Questions de communication [Online], 13 | 2008, Online since 01 February 2014, connection on 08 April 2021. URL: http://

journals.openedition.org/questionsdecommunication/8870 ; DOI: https://doi.org/10.4000/ questionsdecommunication.8870

This text was automatically generated on 8 April 2021 .

Tous droits réservés 


\title{
Collective Responsibility in the Press
}

\author{
Alain Rabatel and Roselyne Koren \\ Translation : Inist
}

\section{EDITOR'S NOTE}

This English translation has not been published in printed form/Cette traduction anglaise n'a pas été publiée sous forme imprimée.

1 While journalism believes in a realist and positivist concept of language that no doubt allows it to justify the impartiality of its coverage (Koren, 1996, 2004), this very concept prevents it from perceiving the discursive tensions inherent in subjectification and objectification. These philosophical concepts are nevertheless often used when claiming to attribute, dilute, or even deny collective responsibility, with the purpose of ensuring that a certain point of view, which would normally require discussion, is taken for granted. It is this doubly complex notion of collective responsibility that we want to examine here, within the framework of the linguistics of discourse which attaches great importance to enunciative phenomena as well as to direct and indirect forms of argumentation (Amossy, 2006). Such discourse, the circulation of which is promoted by its enunciative effacement (Vion, 2001; Rabatel, 2002, 2004) or a claim by a collective utterer, is the venue for important issues in the construction of a constantly evolving 'social mirror' (Charaudeau, 1997, 2005; Moirand, 2000). As an extension of issues 13, 17 and 22 of Semen (2000, 2004a, 2006), which focused on discourse analysis and were respectively dedicated to the different genres of written press, argumentation, and enunciative responsibility in the press, and in consonance with the debates on media criticism, researcher ethics and constructivism that notably inspired issues 4, 5 and 6 of Questions de communication (2003, 2004a, 2004b), this paper aims to further explore and clarify some of the previous questions by focusing on an issue that is problematic in a great many respects: collective responsibility. 
2 Collective responsibility is not the collective guilt of a group, but rather the way in which an individual or a group takes into account the problems of a community that aspires to 'make society'. This issue emerges at very different rates depending on societies and backgrounds. Newspaper articles or viewpoints published by the written press clearly demonstrate that their authors foresee, desire, and theorise a return to politics and changes in the methods of participation in national and international political life. The increasing importance of interdependencies in this era of globalisation primarily raises questions concerning the written press, to which we will confine our discussion. Indeed, the methods of the press paradoxically encourage the depoliticisation of civil society, at a time when a return to politics would seem more urgent and necessary than ever. To the extent that an ethical stance is reflected in discourse, it is logical and legitimate that linguistics and information and communication science realise this and integrate it into their field of application.

In their introduction to issue 22 of Semen, Alain Rabatel and Andrée Chauvin-Vileno (2006) discussed at length the complexity of the concept of responsibility, through its genealogy in philosophy and in the legal sphere, and increased by its articulation with regard to language issues. We intend to summarise the issues of this concept that are relevant to this paper. But let us specify from the outset that this question, which requires taking all necessary scientific precautions to be able to address it in a 'learned' way (Weber, 1919), and not as some kind of prophet of doom, does not exclude the fact that linguists have personal convictions. One of the greatest merits of Chaïm Perelman's work is his insistence on the fact that no intellectual activity, not even the most speculative, is free from personal beliefs, even though these beliefs must always be kept in check by the academic and/or scientific requirements that govern them (Koren, 2002, 2006). In this way, and contrary to popular belief, ethics of conviction and ethics of responsibility should be complementary, which therefore implies a critical review of Max Weber's work (Rabatel, Chauvin-Vileno, 2006: 7).

\section{From philosophical, legal and criminal responsibility to political responsibility}

\section{Responsibility in philosophy}

4 From a philosophical point of view, it is no coincidence that the concept of responsibility in the modern sense of the term appeared during the Age of Enlightenment. Responsibility was considered to be at the heart of a dialectic between subjects and an institution, the latter being strong only to the extent that its members adhered to it, and ensuring their rights and duties in order to avoid the risk of anomie. Responsibility emerged through a complex genealogy. According to Jacques Henriot (1990: 2250), responsibility goes hand in hand with the evolution of ideas and societies, an extension of a quadruple process involving humanisation (responsibility restricted to human beings, as opposed to the responsibility of animals or the 'magical' responsibility of things), individualisation (as opposed to collective responsibility), internalisation (consciousness, free will), and civilisation (the emergence of civil liability, on the basis of primitive criminal liability). This cavalier perspective establishes the concept of collective responsibility in reference to an archaic background of community violence that persists, but without becoming a value, and 
not only in the Western world. The philosophical concept of responsibility claims universality (ethical responsibility is valid at all times and in all places), just like the universality of the human figure, but which is negated by the specifics of legal theories and systems. However, collective responsibility should not be restricted to some kind of attachment to the past, given that it also calls for collective actions supporting the development of institutions that provide a concrete expression of this universality, echoing that of the human figure (see below).

\section{Civil and criminal liability}

5 In legal terms, civil liability requires a person to make compensation for injury or damage caused to others, whereas criminal liability involves the person convicted of an offence under the law being sentenced and punished by the competent courts. This criminal liability, which owes much to Immanuel Kant's analysis of culpability, implies an adult individual, who is rational, self-possessed, conscious of the consequences of his/her actions, capable of discerning right from wrong, and endowed with free will and with volitional and cognitive abilities. While theological, political or scientific issues related to this background (sin, alienation, or biological or psychological determinism) tend to undermine the foundations of responsibility or liability, the majority of critics of free will do not go so far as to question the concepts of choice, deliberation and rational action on the part of the individual (Fischer, 1996: 847). At most, they sustain the idea that the human justice system is flawed, that the act of judging is complex because human beings are incommensurable, and that, consequently, it is essential to take into account the history of the subjects and the weight of the circumstances in order to establish the facts (Danblon, 2002).

But increasing interdependencies have altered the purely individual approach to responsibility ${ }^{1}$. This happened in France, first with the emergence of the concept of moral responsibility (outside that of the State), followed by the administrative responsibility of the State, which received growing recognition during the second half of the nineteenth century, and distinguished between administrative blame, which cannot be individualised, and the culpability or fault of a state employee in the exercise of his/her duties. This extension met with great resistance on the part of the State, heir to the old maxim 'the King can do no wrong'. It also raised questions concerning the appropriateness of an extension likely to lead to a result that was the precise opposite of the desired effect, by diluting responsibilities to an extreme within a framework of overall indeterminate responsibility. This also explains why both moral responsibility and administrative responsibility can be cumulated with personal fault (Le Pors, 1999: 37-40).

\section{Towards a political and social concept of collective responsibility}

7 It is significant that the concept of collective responsibility has been alleged in court to mitigate the responsibility of individuals, on the pretext that a 'chain of responsibility' exists, a 'system', even, in which personal responsibility is non-existent, the individual being a mere 'cog'. Such arguments are null and void in legal terms. Indeed, the role of the law is to recognise individuals and individual responsibilities inserted within the tight framework of other individual responsibilities (the sum of which is not equal to collective responsibility). This is notably the case with medical malpractice, 
occupational diseases and accidents, and allegations of corruption, where doctors, businessmen, government officials or policy makers hide behind collective responsibility or their role as 'underlings' (see, for example, Fleury, Walter, 2005, on the Papon v. France case). One of the most significant textbook cases is that of Adolf Eichmann, both by the magnitude of the crime and the arguments put forward to reduce his personal responsibility, and by Hannah Arendt's comments on his trial (1964). The following example is prototypical with regard to each of these factors, and it will be easily understood why we devote so much space to it.

"Morally speaking, it is as wrong to feel guilty without having done anything specific as it is to feel free of all guilt if one actually is guilty of something. I have always regarded it as the quintessence of moral confusion that during the post-war period in Germany those who personally were completely innocent assured each other and the world at large how guilty they felt, while very few of the criminals were prepared to admit even the slightest remorse. The result of this spontaneous admission of collective guilt was of course a very effective, though unintended, whitewash of those who had done something: as we have already seen, where all are guilty, no one is. [...] Well, if young people in Germany, too young to have done anything at all, feel guilty, they are either wrong, confused, or they are playing intellectual games. There is no such thing as collective guilt or collective innocence; guilt and innocence make sense only if applied to individuals.

Recently, during the discussion of the Eichmann trial, these comparatively simple matters have been complicated through what I'll call the cog theory. When we describe a political system - how it works, the relations between the various branches of government, how the huge bureaucratic machineries function of which the channels of command are part, and how the civilian and the military and the police forces are interconnected, to mention only outstanding characteristics - it is inevitable that we speak of all persons used by the system in terms of cogs and wheels that keep the administration running. Each cog, that is, each person, must be expendable without changing the system, an assumption underlying all bureaucracies, all civil services, and all functions properly speaking. This viewpoint is the viewpoint of political science, and if we accuse or rather evaluate in its frame of reference, we speak of good and bad systems and our criteria are the freedom or the happiness or the degree of participation of the citizens, but the question of the personal responsibility of those who run the whole affair is a marginal issue. Here it is indeed true what all the defendants in the post-war trials said to excuse themselves: if I had not done it, somebody else could and would have. [...]

When I went to Jerusalem to attend the Eichmann trial, I felt that it was the great advantage of courtroom procedure that this whole cog-business makes no sense in its setting, and therefore forces us to look at all these questions from a different point of view. To be sure, that the defence would try to plead that Eichmann was but a small cog was predictable; that the defendant himself would think in these terms was probable [...]. The judges did what was right and proper, they discarded the whole notion [...]. For, as the judges took great pains to point out explicitly, in a courtroom there is no system on trial, no History or historical trend, no ism, antiSemitism for instance, but a person, and if the defendant happens to be a functionary, he stands accused precisely because even a functionary is still a human being, and it is in this capacity that he stands trial. Obviously, in most criminal organisations the small cogs are actually committing the big crimes, and one could even argue that one of the characteristics of the organised criminality of the Third Reich was that it demanded tangible proof of criminal implication of all its servants, and not only of the lower echelons. Hence, the question addressed by the court to the defendant is, Did you, such and such, an individual with a name, a date, and place of birth, identifiable and by that token not expendable, commit the crime you stand accused of, and Why did you do it? If the defendant answers: "It was not I as a person who did it, I had neither the will nor the power to do anything out of my 
own initiative; I was a mere cog, expendable, everybody in my place would have done it; that I stand before this tribunal is an accident" - this answer will be ruled out as immaterial. [...] For to the answer: "Not I but the system did it in which I was a cog," the court immediately raises the next question: "And why, if you please, did you become a cog or continue to be a cog under such circumstances?" If the accused wishes to shift responsibilities, he must again implicate other persons, he must name names, and these persons appear then as possible codefendants, they do not appear as the embodiment of bureaucratic or any other necessity." (Arendt, 1964: 59-63)

8 While the notion of collective responsibility is irrelevant in both legal and moral terms, it makes perfect sense on a political level ${ }^{3}$. Its purpose is not so much to stigmatise a whole community as to question the role of everyone as individuals within a collective undertaking. This role cannot be reduced to nothing, nor can it be assumed indefinitely. Collective responsibility is our responsibility as members of a specific community. It is therefore inalienable (unless we leave the community), but under no circumstances does it make us guilty of actions we have not committed. As Gilles Deleuze (1991: 103) put it, we are not responsible for the victims, but to the victims. From a political point of view, the notion of collective responsibility primarily concerns the individual, when he/she feels responsible for the state of affairs in the world, by extending his/her sphere(s) of belonging. Claiming to be a 'citizen of the world' (one of the aspirations of the philosophy of the Enlightenment) is a constitutive aspiration of the concept of collective responsibility. Historically, this aspiration has been embodied in multiple roles: as a prophet, a sage, an Enlightenment philosopher, a scientist who places his/her knowledge as an expert at the service of society, an intellectual, an official, a spokesperson, a politician, etc. But the representation of collective responsibility is not only embodied in prominent figures. An activist or a citizen who seeks to reconcile his/her actions and discourse, in his/her daily life ${ }^{4}$, can thus claim to embody a part of collective responsibility within the framework of activities that have repercussions on the solving of the world's problems, and that wish to contribute effectively to their resolution ${ }^{5}$.

But the situation is changing with increasing interdependency and the exponential growth in mankind's power of intervention in the twenty-first century, able now to influence the fate of future generations, or even the entire human race (genetic manipulation, for example). This being the case, we can only agree with the view expressed by Hans Jonas (1979: 31):

"The Antigone chorus on the deinotes, the wondrous power, of man would have to read differently now; and its admonition to the individual to honour the laws of the land would no longer be enough. The gods, too, whose venerable rights could check the headlong rush of human action, are long gone. To be sure, the old prescriptions of the 'neighbour' ethics - of justice, charity, honesty, and so on - still hold in their intimate immediacy for the nearest, day-by-day sphere of human interaction. But this sphere is overshadowed by a growing realm of collective action where doer, deed and effect are no longer the same as they were in the proximate sphere, and which by the enormity of its powers forces upon ethics a new dimension of responsibility never dreamed of before."

11 This is why collective responsibility today also includes, in its organisational or institutional aspects: the rise of globalisation (both on the economic and media fronts), the growing number of economic and cultural exchanges, the intermingling of 
populations, the increasing number of cross-border ecological crises, and the similarity of problems in a great many countries. All of these factors have helped create the idea of finding global solutions to global problems, without doing away with actual specificities or strong disparities for all that. The increase in the number of supranational institutions (in times of difficulty), the creation of organisations such as the International Court of Justice in The Hague, the signing of the Kyoto Protocol, and the growing numbers of international meetings (political summits) are indications of the rise of this still faltering sense of collective responsibility, as evidenced by expressions such as 'international politics', 'global regulation', 'good governance', 'global civil society', and so on. This feeling, the expression of which generates many difficulties at institutional level, is also conveyed by intermediate bodies, by certain corporations that are aware of the limits of the corporatist approach, and by nongovernmental organisations. Thus, traces of this concept can be found at all levels of society, at more or less advanced stages.

However, this emergence is fraught with contradictory tensions. Sometimes the feeling of generalised powerlessness and complexity dilutes the sense of responsibility, while at other times the political deficit encourages resorting to scapegoats or the increasingly litigious nature of social relations. The fair consideration of the interests of future generations - a characteristic inherent in the concept of collective responsibility (see Weber, 1919; Arendt, 1964) - has led some, such as Hans Jonas (1979), to put forward a 'heuristic of fear' leading to a precautionary principle, established as a system and hindering the risk-taking inherent in innovation. Just criticism of the shortcomings of democratic institutions can serve to undermine these very organisations and result in reasserting the value of governance by 'experts' or 'wise persons'. This is why collective responsibility attaches great importance to the concept of citizenship in a dialectic that does not preclude universes that are impervious to each other: the public sphere v. the private sphere, the political world v. the legal world, the responsible elite $v$. the irresponsible citizens (or vice versa). Rather, collective responsibility seeks to work towards making room for rationality, which is not restricted to vericonditional rationality but rather seeks axiological rationality, compatible with the requirements of the action. It is in relation to this issue of 'civic education' that we attempt to understand the concept of collective responsibility (see below).

\section{Collective responsibility in the media: the construction, spread and denial of a concept}

13 Our project continues the discussion on the issue of responsibility in linguistics and information and communication science (Rabatel, Chauvin-Vileno, 2006) by questioning how the media portrays collective responsibility, as well as changes in individual responsibility as viewed through the prism of collective responsibility, given that the one does not negate the other. But it is important to first clarify the relationship between this responsibility and the concept of responsibility or commitment in linguistics, before identifying possible main lines of analysis of collective responsibility, and then profiling the latter from the point of view of the ethics of public discourse. 


\section{Commitment, involvement, and personal and collective responsibility} nevertheless implied where the notion of utterer is concerned, defined as one who takes responsibility for his/her utterances (Rabatel 2008). This responsibility, or commitment, results from conversational maxims, notably the principle of sincerity: one is supposed to fully assume the opinions one asserts (if only by default) as primary speaker/utterer, even in the absence of specifically expressed approval or agreement, unlike non-commitment (conditional, epistemic disjuncts, reported discourse, framing, etc.).

Commitment does not correspond to either involvement or disinvolvement, if by that we mean the choice of a specific utterance level': non-implication (non-involvement) on the part of the speaker/utterer when referencing objects of discourse in no way diminishes his/her responsibility. The same is true for the illocutionary force of an utterance. Indeed, the greater the illocutionary force, the more the speaker invests in his/her utterance, but a low degree of illocutionary force does not lead to noncommitment of the vericonditional value of the utterance by the speaker/utterer. Similarly an utterance does not require implication on the part of the speaker to be true, or judged as true, just as its argumentative (rational) value is independent of the commitment of the speaker/utterer, unlike its persuasive value. The referential truth criterion is fundamental in terms of commitment, as is the axiological commitment criterion, which would merit accurate analysis on the basis of the above set of criteria (see footnote 4 above; Koren, 2007).

This line of questioning examines, in particular, the expression of collective responsibility in the media. Indeed, journalists - like other speakers to a certain extent, but perhaps more than most given the public nature of their discourse - are exposed to the expression of circulating terms or points of view that they take up and continue, without always being able to distance themselves from them. This is notably true for terms or analytical frameworks that encourage naturalised representations of the world in which enunciative effacement reigns supreme, even though it may rub shoulders with many axiological arguments. In this case, does not the fact of repeating these views without distancing oneself from them (in the name of objectivity) contribute, albeit indirectly, to the renewal of other ways of seeing and thinking that would also merit discussion? It is significant to note that while journalists readily speak of the ethics involved in naming their sources, they are not so willing to discuss the views underlying the use of certain vocabulary, or portraying certain representations of the social scene (Rabatel, 2006). And it is no doubt also fair to say that the responsibility of the media can be called into question when, unlike the 'metalinguistic silence' mentioned above, it conveys subjective points of view via a certain number of genres (editorials, analyses, reviews, etc.) that tear down some and build up others, fluctuating between non-intervention on the one hand and, at the other extreme, inciting outright rejection, the implicit legitimisation of hate, and so on.

For all of these reasons, the concept of responsibility (accountability) needs to be questioned within the framework of the press, given that the latter represents a venue for public debate. In this respect, we adhere to Emmanuel Levinas's philosophy of personal ethical responsibility to others (Calin, Sebbah, 2002). 


\section{Textual locations of the emergence of collective responsibility}

\section{discourse in the following ways:}

- Distinguishing between speakers/utterers, elites, officials, professionals (from the media), activists and ordinary citizens who explicitly position themselves as sharing this collective responsibility and discourse on this basis.

- Taking into account the influence of the specificity of topics and fields in the discursive use of collective responsibility, where collective responsibility for political, economic, environmental, health, safety, cultural, ideological or religious issues are not treated in the same way within their corresponding fields.

- Analysing the modalities of restitution of such discourse, or even how it is solicited, reported and staged by the media in national and regional daily newspapers, depending on the authors, themes, periods and genres.

This paper therefore analyses some of the locations that discursively produce collective responsibility, as well as those that journalistic discourse tries to ignore:

- Metadiscourse on collective responsibility: implicit or explicit designations (synonyms, antonyms, etc.), lexicalised or not; locations where the emergence of the concept is particularly highlighted, isotopies, names of the agents, stages in accountability.

- Explicit signs (in the dictum and/or the modus) of commitment to the concept of collective responsibility, by clear attribution of responsibilities to a group or by a claim of collective responsibility assumed by the speaker/utterer through formulas that indicate a coincidence between words and things (Authier-Revuz, 1995), such as ' $\mathrm{X}$ is the right word; I dare say X; that which is called X; X; I mean X', where naming is a committed act of demystification, challenging established doxa.

- Explicit signs of distancing through modality and forms of non-coincidence (' $\mathrm{X}$, if you can call it X; X, if we can speak of X') which, by the systematisation of semantic fuzziness and a sort of argument of powerlessness (deliberate or not) to 'say things how they are', serve to cloud what is actually said, encouraging a dilution of the concept of collective responsibility and therefore putting off until later any attribution of collective responsibility.

- Discursive practices that encourage taking a problematic reality for granted: enunciative effacement (Vion, 2001; Rabatel 2005); objectifying discourse (Koren, 1996); stereotypy (Amossy, Herschberg-Pierrot, 1997); testimonies, reporting of facts (Velcic-Canivez, 2006); perceptual evidence (Rabatel, 2005a); prediscourse (Paveau, 2006); effects of circulating discourse, constantly rehashed by a large number of media regardless of their political options (Moirand, Rosiers); discussions on a certain form of default collective responsibility in which evidence plays a significant role in the circulation of discourse, the construction of social identities and ideologies, and the imposition of truth (pensée unique, wooden language).

- Alongside these textual and discursive locations of the emergence of the concept, we will also attempt to analyse the effects of confusion, of 'slip-ups' in discourse attributing or refuting the concept of collective responsibility through the naturalisation of powerlessness, the unilateral attribution of responsibilities to a single source, concealment, and the metalinguistic silence concerning the identity of those to whom we attribute blame'. Problematising, challenging and debating, or complicating ethical issues is not an attempt to 'dilute' responsibility, but rather to assume responsibilities within a system of checks and balances that encourages reflection and discussion and prepares action in an informed way.

Questions de communication, 13 | 2008 


\section{Towards an ethics of public discourse}

work is not without risk - the moralistic posture of the noble-minded, traditionalism, attachment to the past and to aristocratism (see Taguieff, 2007: 78-9) for which we assume full responsibility. In the continuity of the cumulative logic that should be at the heart of linguistics, it seems to us that previous work challenging the uniqueness of the speaker and dealing with enunciative effacement, to which we have contributed, would today require further research on the issues of ethics, responsibility and accountability, and hierarchical organisation. At least two sets of reasons can be invoked here. On the one hand, internal developments in the field of linguistics, which, without rejecting the achievements of structuralism, integrate into the analysis of language interactional and ethical concerns (see Dominicy, Frédéric, 2001; Masseron, 2003) that, far from being confined to literary texts, are fundamental to the study of communicative action. On the other hand, developments external to the field of linguistics, but which nevertheless interact with it. The proliferation of discourse is a given: media specialists measure it every day, and with it, the difficulty of managing multiple sources, to the point that everything seems to be of equal merit. But while it is unrealistic to return to the time of licensed distributors of official discourse or authorised knowledge, it nevertheless seems vital to question by what principles of regulation and hierarchy different knowledge can be built together, reasoning developed, and values defined through confrontation within a place that allows for making society ${ }^{10}$. In this sense, what follows would aim to contribute to an ethics of public discourse, these 'emerging issues', to borrow and modify Caroline Masseron's expression (2003: 3), that we believe it is urgent to expand.

The articles focus on descriptive studies and/or theoretical issues. The corpora of journalistic texts (case studies, longitudinal and quantitative studies) should explore issues of collective responsibility from one or more points of view. We sincerely hope that this work will be carried out based on ethical requirements far removed from any judgemental aim, and with a desire to find ways and means of public expression that allow for dealing with the complex and with conflicts in a sometimes harsh way, but always preferring rhetorical weapons over any and all bellicose policies.

\section{Cross-disciplinary contributions}

The composition of this paper reflects the fact that discourse analysis is deliberately situated today at the crossroads of linguistics, humanities and social sciences. The authors are linguists, discourse analysts (Alain Rabatel, Roselyne Koren), researchers in information and communication science, and sociologists (Jean-Francois Tétu, Gilles Bastin). Moreover, two of them include an argumentative component in their discourse analysis (Ruth Amossy, Roselyne Koren). This does not mean that they have decided to abandon the epistemological differences between them, but rather that all of them have taken into consideration approaches by disciplines other than their own, readjusting concepts borrowed from these disciplines in order to integrate them into their arguments. For all of the authors, however, whether sociologists or discourse and utterance analysts, the priority is the need to contribute, on the one hand, to the conceptualisation of collective responsibility and, on the other hand, to the anchoring 
of this conceptualisation within the textual framework of French and foreign press articles. prism of the definitions of the concept given by Hannah Arendt and Max Weber. Current manifestations of the concept confirm in a very striking way the conceptualisation proposed by these two thinkers. The emergence of a sense of responsibility stems from a crisis situation. Politicians, citizens and civil societies are confronted with very real dilemmas in the face of which they must adopt an attitude of 'realism'. The option of doing nothing is obviously open to them, but they prefer to decide and act, even against their own convictions if necessary. Collective responsibility implies that citizens seek to reconcile ethics of conviction and ethics of responsibility. The metadiscourse of the corpus examined combines individual moral responsibility and collective political responsibility, made inevitable by globalisation. It dissociates guilt and responsibility, responsibility and powerlessness or the fear of acting and thinking against the injunctions of doxa, state responsibility and the responsibility of civil societies, the duty of objectivity on the part of the media and the duty to tell, understood as an exercise of a revisited critical function.

Alain Rabatel anchors his discussion in the discursive and enunciative realities of a debate between Socialist party candidates in the 2007 French presidential pre-election campaign. The goal of his contribution is to move from a simple analysis of an example considered emblematic, to more general considerations. The article problematises the issue of the failure, due to renouncement, to give an argued form to conflicts in the public arena, when ideally the role of mediator should involve the presentation and problematisation of the views of different sections of society, before society as a whole. And yet, the choice of questions retained for the above-mentioned debate was neither explained nor justified. The same was true as regards the omission of key issues. The ethical 'ritual' implied in the duty of 'objectivity' thus fell well short of the expectations authorised by an ethical concept of information. Putting into words and conceptualisation are therefore explored through the prism of the political, social and ethical issues that underlie the linguistic construction of the verb 'to answer', i.e., 'to answer for', 'to answer to', etc.

Jean-François Tétu calls for a redefinition of the journalistic identity within a context of crisis in journalism and representation. The study of public journalism in the United States allows him to problematise the issue of the transformation of journalistic responsibility, hitherto considered as individual, into collective responsibility. Moving from the right of information to the right to information plays a decisive role here. Public journalism abandons the exercise of a critical function and the analysis of conflictual situations. Rather, it prefers to listen to readers and gives priority to a unique form of thought, close to communitarianism. It therefore reinforces the myth of direct democracy, and obliges journalists to redefine the nature and legitimacy of their profession. And while public or civic journalism has never really reached the major newspapers or the major television networks, it has, according to Tétu, represented the starting point for two very recent and widespread phenomena: blogs, or citizens portals, and partnership agreements between large information institutions and civic portals. The conceptualisation of the social or collective responsibility of the media therefore invites the reader to reflect on the virtues and vices of another concept for which there is currently little consensus: the democracy of opinion. 
es Bastin suggests a sociological and discursive examination of articles published in the early 2000s on the subject of the Outreau trial in France, a textbook case. According to Bastin, it is important to highlight and analyse a paradox: the asymmetry that opposed the logic of the anonymisation of the journalistic word, i.e., the systematisation of enunciative effacement and of the effects of objectivity in the reports on the judicial inquiry, on the one hand, and, on the other, the way these same articles expressly named the suspects and demanded that they account for their actions. In this case, therefore, the press assumed the 'exceptional' privilege of 'irresponsibility' precisely where we would have expected it to 'answer to' or 'answer for'... Two discursive strategies strongly contribute to this attitude. Firstly, the generic term of 'the media' that neutralises attribution to the individual and therefore the obligation to take individual moral responsibility for what is written. Secondly, the metaphor of the 'enthusiasm' that complacently sustains the myth that facts have a life of their own, reflected by mirror writing on the part of anonymous mediators who distance themselves from what they write.

Ruth Amossy addresses the issue of the collective responsibility of the written press on the basis of a corpus made up of editorials published in the Israeli newspaper Ha-aretz during the 2006 Lebanon War. These editorials problematise the issue of the conclusions of the Winograd Commission, a commission of inquiry into the role of the government and the army during the war. The members of the Commission claimed that they did not want to decide or to vote for or against the resignation of the political and military officials involved. The question of the respective responsibilities of the press, political bodies and the Commission is examined via a concept of discourse analysis that incorporates an argumentative component. This allows us to begin to understand how a democratic media body works, within a context of crisis, to solve tension between conflicting ethical obligations: respecting the decisions of a democratically elected government, but also fulfilling the role of a critical counterbalance, specific to the political press, and positioning itself against another body, every bit as legitimate as the government (the Winograd Commission). Reported speech and syllogistic construction are scientific concepts that seem far removed from the passions underlying this controversy. Nevertheless, these concepts make it possible to describe, shed light on and problematise the discursive and argumentative practices of journalists who wish to assume personal responsibility within the scope of an ethics of democratic discourse, without exhausting the question of collective responsibility.

\section{BIBLIOGRAPHY}

Adam J.-M., Herman T., éds, 2000, « Genres de la presse écrite et analyse de discours », Semen, 13.

Amossy R., 2000, L'argumentation dans le discours, Paris, A. Colin, 2006.

Amossy R., Herschberg-Pierrot A., 1997, Stéréotypes et clichés, Paris, Nathan. 
Amossy R., Koren R., éds, 2004, « Argumentation et prise de position : pratiques discursives », Semen, 17.

Arendt H., 1964, « Responsabilité personnelle et régime dictatorial », pp. 49-78, in : Kohn J., éd., Responsabilité et jugement, Paris, Payot, 2006.

Arendt H., 1968, « La responsabilité collective », pp. 173-183, in : Kohn J., éd., Responsabilité et jugement, Paris, Payot, 2006.

Authier-Revuz J., 1995, Ces mots qui ne vont pas de soi,T 1-2, Paris, Larousse.

Balibar É., 1997, « Irresponsabilité de la politique, responsabilité du citoyen ?», pp. 285-298, in : Ferenczi Th., éd., De quoi sommes-nous responsables ?, Paris, Éd. Le

Monde.

Calin R., Sebbah F.-D., 2002, Le vocabulaire de Lévinas, Paris, Éd. Ellipses.

Charaudeau Fi, 1997, Le discours d'information médiatique. La construction du miroir social, Paris, Nathan/INA.

- 2005, Les médias et l'information. L'impossible transparence du discours, Bruxelles, De Boeck.

Clero J.-P, Laval Chr, 2002, « Bentham », pp. 763-811, in : Zarader J.-P, coord., Le vocabulaire des philosophes, T. 2. Paris, Éd. Ellipses.

Corcuff Ph., 1997, « De l'heuristique de la peur à l'éthique de l'inquiétude », pp. 383-392, in :

Ferenczi Th., éd., De quoi sommes-nous responsables? Paris,

Éd. Le Monde.

Danblon É., 2002, «Éthique et rhétorique : entre les faits et les normes », pp. 91122, in : Koren R., Amossy R., éds, Après Perelman : quelles politiques pour les nouvelles rhétoriques?, Paris, Éd.

L'Harmattan.

Deleuze G., 1991, Qu'est-ce que la philosophie ?, Paris, Éd. de Minuit.

Dominicy M., Frederic M., éds, 2001, La mise en scène des valeurs, Lausanne/Paris, Delachaux et Niestlé.

Engel L., 1997, « Réguler les comportements », pp. 80-89, in : Férenczi Th., éd., De quoi sommes-nous responsables? Paris, Éd. Le Monde.

Ewald Fn, 1997, « L'expérience de la responsabilité », pp. 11-36, in : Ferenczi Th., éd., De quoi sommes-nous responsables?, Paris, Éd. Le Monde.

Ferenczi Th., éd., 1997, De quoi sommes-nous responsables?, Paris, Éd. Le Monde.

Fischer J.-M., 1996, « Libre arbitre et déterminisme », pp. 842-848, in : Canto-Sperber éd., Dictionnaire d'éthique et de philosophie morale, Paris, Presses universitaires de France.

Fleury B., Walter J., 2005, « Le procès Papon : médias, témoin-expert et contre-expertise historiographique », Vingtième Siècle. Revue d'histoire, 88, pp. 63-76.

Henriot J., 1990, « Responsabilité », pp. 2250-2253, in : Auroux S., éd., Encyclopédie philosophique universelle. Les notions philosophiquesT2, Paris, Presses universitaires de France.

Jonas H., 1979, Le principe responsabilité Une éthique pour la civilisation technologique, trad. de l'allemand par J. Greisch, Paris, Flammarion, 1998.

Koren R., 1996, Les enjeux éthiques de l'écriture de presse et la mise en mots du terrorisme, Paris, Éd. L'Harmattan. 
- 2002, « « La nouvelle rhétorique » : « technique » et/ou « éthique du discours »; le cas de l'engagement du chercheur ", pp. 197-228, in : Koren R, Amossy R, éds, Après Perelman : quelles politiques pour les nouvelles rhétoriques?, Paris, Éd. L'Harmattan.

- 2004, «Argumentation, enjeux et pratiques de Rengagement neutre » : le cas de l'écriture de presse ", Semen, 17, pp. 19-40.

- 2006, «La responsabilité des Uns dans le regard des Autres : l'effacement énonciatif au prisme de la prise de position argumentative », Semen, 22, pp. 87-94.

- 2008, «L'analyse du discours au prisme d'un questionnement éthique », Revue de philologie et linguistique portugaise, Universidade de Sâo Paulo, à paraître.

Krieg-Planque A., 2006, « L'intentionnalité de l'action mise en discours. Le caractère intentionnel des crimes de masse sur la scène médiatique ", pp. 88102, in : Le Pape M., Siméant J., Vidal C., dirs, Crises extrêmes. Face aux massacres, aux guerres civiles et aux génocides, Paris, Éd. La Découverte.

Le Pors A., 1999, La citoyenneté. Paris, Presses universitaires de France.

Masseron C., éd., 2003, « Textes et valeurs : une problématique didactique en émergence », Pratiques, 117-118, pp. 3-7.

Moirand S., 2000, « Du traitement différent de l'intertexte selon les genres convoqués dans les événements scientifiques à caractère politique ", Semen, 13, pp. 97-118.

Paveau M.-A., 2006, Les prédiscours, Paris, Presses de la Sorbonne nouvelle.

Questions de communication, 2003, « Sur l'engagement des chercheurs », 4, pp. 241-287.

- 2004a, « Des usages du constructivisme », 5, pp. 161-21 I.

- 2004b, « Des usages du constructivisme (2) », 6, pp. I0I-I77.

Rabatel A., 2004a, «Effacement argumentatif et effets argumentatifs indirects dans l'incipit du Mort qu'il faut de Semprun ", Semen, I7, pp. III-I32.

- éd., 2004b, « Leffacement énonciatif dans les discours représentés », Langages, I56.

- 2005, « Effacement énonciatif et argumentation indirecte. "On-perceptions", "onreprésentations" et "on-vérités" dans les poins de vue stéréotypés », pp. 85-

I I6, in : Raccah P-Y, éd., Signes, langues et cognition, Paris, Éd. LHarmattan.

- 2006, «L'effacement de la figure de l'auteur dans la construction événementielle d'un "journal" de campagne électorale et la question de la responsabilité, en l'absence de récit primaire ", Semen, 22, pp. 7I-85.

- 2008, « Prise en charge et imputabilité, ou la prise en charge à responsabilité limitée », à paraître.

Rabatel A., Chauvin-Vileno A., 2006, « La question de la responsabilité dans l'écriture de presse », Semen, 22, pp. 5-27.

Rabatel A., Grossmann F., éds, 2007, « Figures de l'auteur en didactique »,

Lidil, 35.

Taguieff P-A., 2002, L'illusion populiste, Paris, Flammarion, 2007.

Trigeaud J.-M., 1990, « Responsabilité juridique », pp. 2254-2258, in : Auroux S., éd., Encyclopédie philosophique universelle. Les notions philosophiques, T. 2. Paris, Presses universitaires de France.

Velcic-Canivez M., 2006, Prendre à témoin, Paris, Ophrys. 
Vion R., 200I, « "Effacement énonciatif" et stratégies discursives », pp. 33I-354, in : de Mattia M., Joly A., éds, De la syntaxe à la narratologie énonciative, Paris, Ophrys.

Weber M., I9I9, Le savant et le politique, trad. de l'allemand par J. Freund, Paris, Plon, 1963.

\section{NOTES}

1. In legal terms, notably, the concept of responsibility or liability draws not only on the concept of fault, but also on that of liability without fault, or strict liability, which is compassionate in nature, and which is at the centre of the concept of compensation for damage (see Ewald, 1997; Engel, 1997: 80-82).

2. It is interesting to note that, according to Jean-Pierre Cléro and Christian Laval (2002: 806 et seq.), Jeremy Bentham was one of the first to broach the subject of the individual responsibility of persons holding public office. Bentham even tried to accentuate this individual responsibility, because, from his utilitarian perspective, the refusal to dilute responsibility met the requirements for maximum efficiency. At first view, this approach was rather unexpected for a theory that preferred to emphasize the flaws in official structures rather than the faults of individuals, but it was precisely because of the inertia of these structures that Bentham called for a strengthening of individual responsibility.

3. It is a case here of general political responsibility, not the individual responsibility of the politicians (Le Pors, 1999: 41-44).

4. For example, as a law-abiding driver, a user who makes decisions in the interest of the public good, or an environmentally-responsible consumer. In this sense, whenever individual behaviour is justified by concern for others at any level whatsoever, collective responsibility is built. Of course, the consequences of this practical exercise in collective responsibility (assumed or denied) are not the same depending on the role of the individuals concerned, but this should not constitute a reason for doing away with reflection on this particular type of collective responsibility.

5. According to Hannah Arendt (1968: 183), no individual and personal moral standard of conduct can excuse us from collective responsibility. For her, this delegated responsibility for things we have not done, in other words, the way we take responsibility for the consequences of things for which we are completely innocent, is the price we have to pay both in order to live our lives among our fellow human beings, and so that the ability to act, that political right par excellence, can be expressed in one of the many and varied forms of human community.

6. These contradictions are what led Philippe Corcuff (1997: 385-387) to both agree and disagree with Hans Jonas, and to maintain the relevance of Ernst Bloch's 'principle of hope', i.e., utopia, even though it meant suggesting a less messianic approach than those proposed by Bloch and, especially, Karl Marx (refer also to the analysis by Étienne Balibar, 1997).

7. This issue must be distinguished from all other forms of explicit expression of the exercise, refusal, denial, or even impossibility of collective responsibility.

8. See the article by Jean-Claude Guillebaud (Nouvel Observateur, 5-11/04/90, pp. 46-48) on the subject of the Romanian Revolution in Timisoara, 'Cinq jours de dérapage médiatique analysés heure par heure. Roumanie : qui a menti? [italics ours]'. While the article describes this revolution as a 'textbook case', the very rhetoric of putting it into words takes on the qualities of a perfect example of enunciative effacement, naturalisation, and discursive and argumentative strategies to sidestep the act of explicitly assuming responsibility.

9. This issue could be addressed with regard to corpora of journalistic texts dedicated to the coverage and analysis of different types of crises (political, military, economic, environmental, 
etc.). In this case, the issue of collective responsibility makes sense in the area of politics, understood as an area of deliberation and democratic resistance to totalitarianism. On a thematic level, this issue refers specifically to multiple strategies to incite collective hatred, or to strategies of blaming some in order to better exonerate others (refer to the various discussions on colonialism, the slave trade, etc.).

10. This is one of the reasons that motivated the theme of issue 35 of Lidil devoted to the growing complexity of the author figure and the ensuing difficulties for the learner facing a nonhierarchical multiplication of enunciative sources and frameworks of knowledge (Rabatel, Grossmann, 2007).

\section{AUTHORS}

\section{ALAIN RABATEL}

Interactions, Corpora, Learning, Representations (ICAR)

CNRS

Université Lyon 2 IUFM

Université Lyon 1

at.rabatel@orange.fr

\section{ROSELYNE KOREN}

Discourse analysis, argumentation, rhetoric

Bar-Ilan University, Ramat-Gan

korenr1@maiLbiu.ac.il 